\title{
USE OF POLITICAL AND IDENTIFICATION WORDS "PARTY OF UKRAINE", "TOGOBIC UKRAINE", "BOTH SIDE OF THE DNEPR", "THIS SIDE OF THE DNEPR" (1673 - 1686)
}

\section{Taras Chukhlib}

ORCID: https://orcid.org/0000-0002-2604-4816)

DSc (History)

Institute of history of Ukraine, NAS of Ukraine

4, Hrushevskoho Str., Kyiv, 01001, Ukraine

kontrabas20@ukr.net

The article describes the terminological essence of such historical concepts as "the Dnieper side", "the other side of the Dnieper", "the two-sided Ukraine", "this Dnieper side". On the basis of diachronous-semantic analysis and other methods of study of texts of official documentation of the Zaporozhye, Crown of Poland and Moscow Kingdom for 1673 - 1687, it is proposed the following important conclusion: these conceptual phrases are widely used by the officials of these states in several semantic meanings, in particular, denoted both the Right Bank and the Left Bank of Ukraine. Also it was revealed that the territory under the former Eastern provinces of the PolishLithuanian Commonwealth received the permanent political name "Ukraine", and also had other synonymous names - "the side of the Dnieper", "the two-sided Ukraine". The same name the Left-Bank districts ("regiments") of the Zaporozhian Troops had, which were politically dependent on the Moscow kingdom and were also labeled as "the Dnieper Ukraine", "the other side of the Dnieper." This semantic-synonymous series was reflected in the diplomatic and governmental correspondence of the states of Central, Eastern and Southeastern Europe. In addition, at this time, such language phrases of localization-ethnonymic character as "Ukrainian people" functioned.

Key words: "Ukraine", Zaporozhian Army, "Ukrainian people", "Dnieper side", "Transdnieper side", Petro Doroshenko, Ivan Samoilovich.

Tарас Чухліб

ORCID: https://orcid.org/0000-0002-2604-4816 Доктор історичний наук, провідний науковий співробітник Інституту історії України НАН України Вук. Грушевського, 4, Київ, 01001, Україна kontrabas20@ukr.net

\section{УЖИВАННЯ ПОАІТИКО-ІДЕНТИФІКАЦІЙНИХ САОВОСПОАУЧЕНЬ "СТОРОНА УКРАЇНИ", "ТОГОБІЧНА УКРАЇНА", "ОБОХ СТОРІН ДНIПРА", "ТОЙ БІК ДНІПРА", “ЗАДНІПРСЬКА СТОРОНА" (1673 - 1686 рр.)}

у статті розкривається термінологічна сутність таких історичних понять як "сторона Дніпра", "той бік Дніпра", "тогобічна Україна", "Задніпрська сторона". На основі діахронно-семантичного аналізу й інших методів дослідження текстів офіиійної документаиї Війсъка Запорозъкого, Корони Польсъкої та 
Московського иарства за 1673 - 1687 рр. автор робить такий важливий висновок: дані понятійні словосполучення у зазначений період широко використовуються урядовиями иих держав у кількох семантичних значеннях, зокрема позначала як Правобережну так і Аівобережну Украйни. Також вчений підсумовуе, шо підлегла Війську Запорозькому територія у межах колишніх східних воєводств Речі Посполитої отримала сталу політичну назву "Україна", а також мала інші синонімічні самоназви - "сторона Дніпра", "тогобічна Украӥна". Так само називалися $і$ лівобережні полки Війсъка Запорозького, які були $у$ політичній залежності Московського иарства таз маркувалися ше $i$ як "Задніпрська Украӥна", "той бік Дніпра". Цей семантично-синонімічний ряд відображався у межах дипломатичної та урядової переписки держав Центральної, Східної та Південно-Східної Свропи. Окрім того, у ией час фуннкіонували такі мовні словосполучення локалізаиійно-етнонімічного характеру як "українсъкий народ".

Ключові слова: "Украӥна", Війсъко Запорозъке, "украӥнсъкий народ", "сторона Дніпра", "Задніпрська сторона", Петро Дорошенко, Іван Самойлович.

Нами вже неодноразово висвітмювалися різні проблеми діахронносемантичного наповнення багатьох мовних понять Війська Запорозького, які мали у своїй основі словотворчу одиницю "Україна", а також тлумачилися похідні від нього понятійні слова та словосполучення. Зазначимо, що у попередніх розцогих розвідках, що буми опубціковані в академічному щорічнику "Україна в Центрально-Східній Свропі" протягом 2015 - 2018 рр., розкривався історико-лінгвістичний матеріал, який вивчав такі понятійні моделі як "Українська держава", "Український народ", "Українські козаки", "мима отчизна Україна" тощо [12-16]. У даній статті хочемо ознайомити наукову спільноту з нашими дослідженнями, які у хронологічному відношення охоплюють 1673 - 1686 рр., тобто роки, коли Українська держава, що виникла за гетьманування Богдана Хмемьницького вже була розділена на два великих державних утворення - Правобережну i

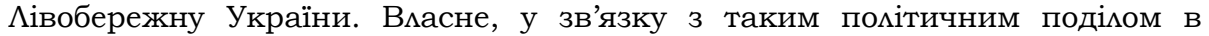
офіційному дискурсі колись єдиного Війська Запорозького і виникають досліджувані нами термінологічні поняття. У статті аналізується джерельний матеріал, який стосується останніх років гетьманування Петра Дорошенка на Правобережній Україні, а також періодів правління Юрія Хмельницького (частина Правобережжя) та Івана Самойловича (Аівобережжя).

$* * *$

Понятійні словосполучення "сия сторона Днепра", "она сторона Днепра" $є$ дуже давніми і зустрічаються вже у мітописах давньої РусіУкраїни. При цьому слово “сторона" в окремих випадках писалаося як "страна", а займенники "она" и "сия" вживалися в залежності від місця знаходження мітописця та мокамізували Правобережжя або Аівобережжя. Наприклад, в Іпатіївському зводі мітописів у записі за 1193 р. читаємо: "Боурчевичи приьхаша по онои сторонь Дньпра противу Канева и не Бхаша на ону сторону, но рекоша Святославоу и Рюрикови: аж вам мюбо, едите к нам на сию сторону" [9, с. 21-24].

У мисті кошового отамана Запорозької Січі Аук'яна Андрієвича 3 Чортомиика від 9 січня 1673 р. до мівобережного гетьмана Івана 
Самойловича не тільки кілька разів згадується слово "Україна", але й вживаються такі прості й складні мокалізаційні словосполучення як "ця сторона Дніпра»" , "ваша сторона", "вся Україна»: "1) "...Турський салтан до нього (Петра Дорошенка. - Т. Ч.) пише цими словами, щоб у өсій Україні вогнем попалики на иій стороні дніпра (Правобережжі. - Т. Ч.) і на вашій стороні (Аівобережжі. - Т. Ч.)..." [5, т. ХІ, с. 112-113]. Як бачимо, $\Lambda$. Андрієвич називав Мівобережну Україну "вашою стороною [Дніпра]" та застосовував щодо неї займенник "ваша", тобто визнавав, що вона у політичному відношенні підпорядковувалася гетьману Івану Самойловичу. При цьому кошовий отаман називав правобережне Військо Запорозьке, що знаходилося під монаршою владою турецького султана Мегмеда IV Авджи та підпорядковувалося гетьману Петру Дорошенку в одному випадку "цією стороною Дніпра", а в іншому - «всією Україною" [про відносини султана Османської імперії Мегмеда IV Авджи та гетьмана Петра Дорошенка див. докладніше у нашій статті: 12, с. 93-135]. Окрім того, одночасно "всією Україною" $\Lambda$. Андрієвич також маркує Аівобережжя, Правобережжя $\mathrm{i}$ Запорожжя.

Воєвода московського гарнізону в Києві Г. Козцовський у своїй відписці до Москви від 28 мютого 1673 р. зазначав, що житель м. Переяслава грек Павцо Ростан приїхав до міста Баришівка на Київщині і розповів, що (мовою оригіналу): “И Яков де Аизогуб говорим: ведомо им чинитца, что по указу Его Царского Пресветлого Величества, гетман Иван Самойлович с Войском Запорожским хочет переходить на my сторону Днепра на Дорошенка и на них войною; да и та ведомость есть, что Великий Государь, Его Царское Пресветлое Вемичество, своею государскою особою будет на Украине..." [5, т. ХI, c. 165-166]. Цікаво, що ще один грек, житель Константинополя (Стамбула) купець Һеонтій Ходжи Ардан у той же час розповідав московським представникам, що "приехал он в малороссийские городы из Волоской земли из города Яс...; А что де вецикий государь изволит своею Царского Величества особою во многих своих государских силах на Украину итти, того он в Волоской земле не слыхал. А тое стороны Днепра черкасскими городами идучи, слышах" [5, Т. ХІ, c. 178]. Тут в одному семантичному ряду поряд 3 "Україною" вживаються така власна назва як "Волоська земля", а "та сторона Дніпра" (очевидно, що йшлося про Правобережжя) означується ще як "черкаські городи".

У грамоті царя Московської держави Олексія Михайловича до київського митрополита Йосифа Тукамьського від 17 березня 1673 р.

\footnotetext{
2 Понятійні словосполучення "сия сторона Днепра", "она сторона Днепра" є дуже давніми і зустрічаються вже у мітописах давньої Русі-України. При цьому слово "сторона" в окремих випадках писалося як "страна", а займенники "она" и "сия" вживалися в залежності від місця знаходження мітописця та мокалізували Правобережжя або Аівобережжя. Наприклад, в Іпатіївському зводі Аітописів у записі за 1193 рік читаємо: "Боурчевичи приЬхаша по онои сторонь дньпра противу Канева и не ьхаша на ону сторону, но рекоша Святославоу и Рюрикови: аж вам Аюбо, едите к нам на сию сторону" [9, с. 21-24].
} 
читаємо: "...Дия чего между нас Вемиким Государем, Нашим Царским Величеством, и братом нашим, Великим Государем, Его Королевским Величеством, и в Андрусовском договоре постановлено украине заднепрской стороны бытии под владением Его Королевского Величества" [5, т. XI, с. 204]. Якщо в мовному тезаурусі московського протектора мівобережного Війська Запорозького уживалася така мексична модемь як "Україна задніпрської сторони", то значить мусила бути й "Україна незадніпрської сторони", тобто та, яка була не 3 "вемикогосударського боку" - Правобережна Україна.

26 червня 1673 р. московський цар отримав миста від польського короля Михайла Корибута Вишневецького в якому говорилося: "...зволила його царська вемичність через піддячого Прокопа Возниціна об'явити королівської величності послам поданий був зі сторони його царської величності спосіб відізвання Дорошенка від салтана турського, коли б його королівська величність з Україною, на тій стороні Дніпра будучею, під володіння його царській величності уступив...; По достоїнству його королівської величності посли при 4 статті Андрусівського договору стояли, в якій написано, що через перемирний час ніхто із них вемиких государів один другому государю в сторону України вступатись не має» [5, т. XI, c. 370].

10 березня 1674 р. московський цар у мисті до момдавського господаря Ш. Петричейку писав: “..Указали Украину тое стороны Днепра усмирить и со семи владеньями и землями вашими хотите быть под нашею великого государя самодержавною высокою рукою в подданстве" [10, c. 17]. Як бачимо, "Україну на тій стороні Дніпра" можна було "уступити", тобто передати під помітичну зверхність від одного монарха іншому. Також "Україну тієї сторони Дніпра" (тобто - Правобережжя) треба було "усмирити", адже вона як суб'єкт тогочасних політичних відносин не хотіла визнавати владу московського царя.

В інформації, яка надійшла 20 березня того ж року до Варшави 3 Меджибожа зазначалося, що "Гетьманом на mій стороні від дніпра, \изогуб (?), підтримуваний Москвою... Дорошенко з воєводами не хоче підтримувати стосунків" [1, s. 1421]. 20 мипня до гетьмана Івана Самоймовича звертається полковник Подільського полку Михайло Зеленський: "...А якщо мяшські війська наступлять, то договори з ними чинити, а на нас війну все обернути і на всю обох сторін Дніпра Україну" [5, с. 540]. Під час переговорів з московськими послами влітку того ж року Петро Дорошенко виголосив промову, яка була записана царськими посланцями й увійшла до історіографії під назвою (мовою оригіналу) "Речь Гетмана Петра Дорошенка, изьявцяющая выгоды к принятию им Российского подданства". При цьому слово "Україна" вживалося гетьманом неодноразово та у різних смислових комбінаціях. Насамперед, потрібно зазначити, що правобережний гетьман чітко вживав його як політичну назву країни, тобто, політонім, яка перебувала під його владою: "...вірний підданий Його Царській Величності буду, з усією стороною Украӥни, яка під моєю владою знаходиться" [У російському перекладі: "...верный 
подданный Его Царского Вемичества буду, со всею стороною Украйнъ, которая под моею вмастию обретается»: 7, с. 259].

24 січня 1675 р. у мисті кошового отамана Івана Сірка до короля Речі Посполитої Яна III Собеського повідомлялося, що із Запорозької Січі до Помьщі було споряджене посольство, яке "тим боком Дніпра дмя безпеки відправилося" [3, s. 211]. У мисті від 18 вересня 1676 р. до охотницького полковника I. Новицького мівобережний гетьман I. Самойлович писав: "...Богу від усіх нехай буде благодаріння, понєваж отиизну нашу розторгнену Україну привів під сдиного монарха $і$ регімент (управління гетьмана - Т.Ч.) y з'єднання" [8, арк.111-112; 2, s. 14-15]. Даний фрагмент тексту дуже цікавий з огляду на розуміння гетьманом Самойловичем політичної роз'єднаності "обох сторін Дніпра" між двома державами та пропозиції вирішення даної проблеми шляхом її об'єднання під скіпетром одного монарха.

6 мютого 1677 р. у черговому посланні до московського царя Федора Олексійовича гетьман Іван Самойлович писав 3 Батурина (мовою оригіналу): "...Как бы нас Войско Запорожское и святое православие искоренити и в ни во что обратити (а не токмо зде ө Украине, но и в Аитве и по Бемой Руси на поругание всему нашему махоросийскому народу церкви Божии православные униатам гонити и $\mathrm{k}$ унии насилством принуждати и привращати поволили)...; давно совершенно с тое стороны Украину, не имея в руках своих Турком при принужденных... к поко договорах, кроме сей стороны...; на сю сторону Днепра целости здоровья своего, приехал в Белу Церковь и тогда сей нынешней комендант белоцерковский безвинно толь знатного на Украине человека, особого своего некоего отмщения досадительства, с сего света погубим..." [5, т. XIII, с. 19-20].

6 мютого 1677 р. посол Війська Запорозького до московського царя Іван Мазепа розповідав у Малоросійському приказі: "на сей и на той сторонах Днепра, милости Божии и великого государя праведными молитвами и счастием, дал Бог, все смирно...; Карпа Мокреева, бывшего писаря войскового при Многогрешном, из Украины с жжено и с детьми и с животы выслать вон...; Гоголь отзываясь с королевские стороны полского [короля] казацким гетманом, стоит на Поцесье близко Киева и присылает в Украину на сю сторону Днепра прелесные свои мисты, устрашивая войски королевского величества и турского салтана приходом под Киев и на өсю Украину..." [5, т. XIII, с. 23-24]. 6 березня того ж року гетьман Іван Самойлович писав до Москви: "...Понеже я со всем Войском Запорожским и народом обосторонним иелое Украины пребываю...; неложно удерживаю и обнадеживаю, шатающихся с Украины по сторонам [Днепра] к себе привлекаю" [5, т. XIII, с. 33, 35]. У даному випадку бачимо дуже цікаве висловлювання - «народ обохсторонній цілої України".

У дипломатичній інструкції за 1677 р., яка була надана посомьству Війська Запорозького до Московського царства й називалася "Інструкція до Великого Государя нашого, до Його Царської Величності, від мене гетьмана Івана Самоймовича, гетьмана Війська Його Царської Пресвітлої Величності 
Запорозького, і усієї військової Генеральної Старшини, іменем усіх Полковників, Сотників, Осавулів, Отаманів і меншого Війська Запорозького, городового товариства і поспольства Народу Українсъкого, в потрібних справах його ж Великого Государя і наших військових, послам нашим, особам військовим генеральним, Івану Домонтовичу судді, Саві Прокоповичу писарю, дана в Батурині, 1677 року, березня в 6 день" у другому пункті говорилося: "2. Також і з иеї сторони війсъко правління мого, які б послали туди дмя оборони, особливо тих полків подніпрських,

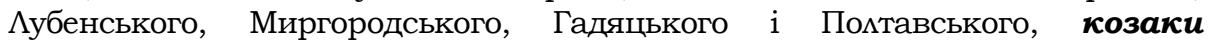
Українсъкі, які поблизу Чигирина і Запорожжя знаходяться, не тільки не встигли б підти..., а інші до Поляків йшли з Украӥни, а інші до Турків і в інші в які держави сторонні" [5, т.XIII, с. 39]. Під час переговорів у Москві було зазначено: "...Могла б та фортеця (Чигирин. - Т. Ч.) в цілості на славу Його Великого Государя в Україні тим образом затриматися, і всю Україну, $\boldsymbol{a}$ особливо сю сторону, від небезпеки оборонити...; А не затримав би тієї чигиринської кріпості, розсудя усі небезпеки воїнські, переживаємо, щоб той мукавий поганець, прийшов у $\boldsymbol{m y} \boldsymbol{m a \boldsymbol { M }}$ Україну $\boldsymbol{i}$ сторону, не похотів на сю сторону Дніпра 3 усіма сиками, не займаючи Києва, переправитися, від якого було б недобре, позбав Боже не тільки Україні Mariŭ Pociï, але i Beruкiŭ в той час, чого не бажаємо щоб було" [5, т. XIII, c. 41-42].

Слово "Україна" та словосполучення "обох сторін Дніпра" вживається у царській грамоті від 29 березня 1677 р. на імя гетьмана Івана Самойловича: «...И тебе Нашего Царского Величества подданого, обох сторон днепра гетмана Ивана Самойловича, и все Войско Запорожское и весь малоросийский наро9д и Украину... от неприятемей Нашего Царского Величества многими ратными Аюдьми защищаем" [5, т. XIII, с. 86].

У травні 1677 р. розвідник Василь Новак, що знав турецьку мові і три тижні перебував у турецькому таборі, засвідчував: "Про Хмельниченка сказав, що безперечно розстрижений і з військами турськими буде, щоб його в Україні осадити і українсъкий народ тим зручніше до себе через нього прилучити; і для того таке між Турками є прислів'я: вміємо ми возом зайців у полі мовити; ... і дмя того начебто вперед висланий [Свстафій Астаматій], щоб усі Українні городи той-там сторони, в яких осадні мюди польські живуть, забрав, за постановою польського [короля] з Турками на договорах, що Украӥні бути при турках" [5, т. XIII, с. 124-125]. 11 серпня 1677 р. гетьман Самойлович писав до царя: “...Похотели изнова каким ни есть образом во время нынешнее опасное нечто змое в Украину, как они обыкли, сослався с иными единомысленники, которые на той стороне Днепра обретаютца, всчать" [5, т.XIII, с. 233].

В універсалі від 10 травня 1682 р., який був підписаний "Їх царського пресвітлої величності Війська Запорозького обох сторін Дніпра гетьманом Іваном Самойловичем", відзначалося про "өигублення тогобіиної України Малоросійської, милої отчизни нашої", "тогобічну опустілу Україну", тобто Правобережжяя. Гетьман Самойлович, згідно з цим документом, збирався заселити "тогобічну Україну" "цъогобічними з регіменту нашого людъми" $[11$, с. 776$]$. У відповідь на закличні універсали Яна III Собеського, 10 травня 
1682 р. вийшов універсал I. Самойловича з Батурина до старшини Війська Запорозького, війтів та бурмистрів та "усього поспольства" про заборону переходити на "правий берег" Дніпра до польського короля: "поляки... вигубили i спустошили тогобічну Україну Малоросійсъку, милу отиизну нашу" [4, с. 167].

А ось як гетьман Іван Самойлович реагував на укладення Вічного миру 1686 р. між Варшавою та Москвою: «...Поневаж ще ще ні в чому мирним договорам кінця не вчинено і з сторони польської не закріплено, а уж сторона польсъка так рано поривається до обняття тогобічної України, назначаючи осадчих, і оголошуючи слободи... Від нас те відлучено не буде, якщо розуміємо так у тих вічного миру договорах утрактовано, що всі народи тутейші украйнсъкі і все військо як городове, так низове вічно знаходитися мають в богохранимій Їх Царського Пресвітмої Величності державі» [6, арк. 389 - 392].

Таким чином, на основі діахронно-семантичного аналізу й інших методів дослідження текстів офіційної документації Війська Запорозького, Корони Польської та Московського царства за 1673 - 1686 рр. можна підсумувати, що досліджувані понятійні словосполучення у зазначений період широко використовуються урядовцями цих держав у кількох семантичних значеннях, зокрема позначали як Правобережну так i Аівобережну України.

Відзначимо також і той факт, що підлегла Війську Запорозькому територія у межах колишніх східних воєводств Речі Посполитої отримала сталу політичну назву "Україна", а також мала інші синонімічні самоназви "сторона Дніпра", "тогобічна Україна". У залежності від ситуації (3 Правобережжя чи Мівобережжя походима документація) так само називалися і мівобережні полки Війська Запорозького, які були у політичній залежності Московського царства та маркувалися ще і як "Задніпрська Україна", "той бік Дніпра". Такі історико-лінгвістичні конструкції об'єднувалися таким інтегруючим словосполученням як "обох сторін Дніпра". Цей семантично-синонімічний ряд відображався у межах дипмоматичної та урядової переписки держав цього регіону Європи.

\section{Джерема та мітература:}

1. Acta historica res gestas poloniae illustrantia ab anno 1507 usoue ad annum 1795. Pisma do wieku i spraw Jana Sobieskiego / Zebr. Fr. Kluczycki. - Vol. 1. - Pars. I. Kraków, 1881.

2. Wołinski J. Król Jan III a sprawa Ukrainy. Warszawa, 1934.

3. Woliński J. Materiały do dziejów wojny polsko-tureckiej 1672-1676 // Sdudia i materialy do historii wojskowosci Polskiej. - T. XIII. - Cz. 2. - Warszawa, 1967.

4. Акты, относящиеся к истории Западной России, собранные и изданные Археографическою комиссию. - Т. V. - СПб., 1853.

5. Акты, относящиеся к истории Южной и Западной России, собранные и изданные Археографическою коммисиею. - Т.XI-ТXIII. - СПБ., 1879-1884.

6. Архів Головний Актів Давніх у Варшаві. - Ф. "Архів публічний Потоцьких", № 47. Т. 1, арк. $389-392$.

7. Бантыш-Каменский Д. Н. Источники малороссийской истории. - Ч. 1. - Москва, 1858. 
8. Бібліотека Музею князів Чарторийських у Краковів, віддім рукописів. - Од. зб. 423, арк. 111-112.

9. Вимкул Т. Сторона/Страна: словоупотребление и географические представмения метописцев XII в. // Восточная Европа в древности и средневековье. Материалы конференции. - Москва, 2000. - С. 21 - 24.

10. Исторические связи народов СССР и Румынии в XV - начале XVIII в. Документы и материалы в 3-х томах. - Т. III. - Москва, 1970.

11. Універсали українських гетьманів від Івана Виговського до Івана Самойловича (1657 - 1687). - К., 2004. - С. 776.

12. Чухліб Т. «Цісар Турецький дозволяє Козацькому Війську та його державі плавати по Чорному морю...": помітичні відносини українських гетьманів з султаном Мегмедом IV Авджи // Україна в Центрально-Східній Свропі. - Вип. 9 - 10. - К., 2010. - С. 93 - 135 .

13. Чухліб Т. Назви "Україна" та "Українний" в офіційному тезаурусі держав Східної Європи та Малої Азії // Україна в Центрально-Східній Європі. Вип. 18. - К., 2018. - С. 13 - 60.

14. Чухліб Т. Поняття "Україна" та "Українний" в офіційному дискурсі Війська Запорозького: 1649 - 1659 рр. // Україна в Центрально-Східній Європі. Вип. 15. - К., 2015. - С. 13 - 41.

15. Чухліб Т. Поняття "Україна", "Український", "Українська держава" в офіційному дискурсі Війська Запорозького (1659 - 1665 рр.) // Україна в Центрально-Східній Європі. - Вип. 16. - К., 2016. - С. 13 - 46.

16. Чухліб Т. Поняття "Україна", "Український", "отчизна", "народ" в офіційному дискурсі Війська Запорозького (1666 - 1672 рр.) // Україна в ЦентральноСхідній Європі. - Вип. 17. - К., 2017. - С. 41 - 79.

17. Чухліб Т. Поняття "Україна", "Українські козаки", "Український народ” в положеннях Андрусівського перемир'я та міжнародній офіційній документації 1667 року / / Україна між Помьщею та Росією. Матеріали Міжнародної науково-практичної конференції. - К., 2016. - С.90 - 99.

\section{References:}

1. (1881) Acta historica res gestas Poloniae illustrantia ab anno 1507 usque 1795. Kraków, Vol. 1, Cz. 1. [In Polish]

2. Akty, otnosyashhyesya $\mathrm{k}$ istoryy Yuzhnoj $\mathrm{y}$ Zapadnoj Rossyy, SPb., 1873. [In Russian]

3. Wołinski J. (1934) Król Jan III a sprawa Ukrainy. Warszawa [In Polish].

4. Woliński J. (1967). Materiały do dziejów wojny polsko-tureckiej 1672-1676. Sdudia $i$ materialy do historii wojskowosci Polskiej. T.XIII. Cz. 2. Warszawa [In Polish]

5. Bantysh-Kamenskiy D. N. (1858) Istochniki malorossiyskoy istorii. CH. 1. Moskva [In Russian]

6. Vilkul T. (2000) Storona/Strana: slovoupotrebleniye i geograficheskiye predstavleniya letopistsev KHII v. Vostochnaya Evropa v drevnosti i srednevekov'ye. Materialy konferentsii. Moskva [In Russian]

7. Chukhlib T. (2010). "Tsisar Turets'kyy dozvolyaye Kozats'komu Viys'ku ta yoho derzhavi plavaty po Chornomu moryu...": politychni vidnosyny ukrayins'kykh het'maniv $z$ sultanom Mehmedom IV Avdzhy. Ukrayina v Tsentral'no-Skhidniy Yevropi. Kyiv. Vol. 9 - 10. [In Ukrainian]

8. Chukhlib T. (2018.) Nazvy "Ukrayina" ta "Ukrayinnyy" v ofitsiynomu tezaurusi derzhav Skhidnoyi Yevropy ta Maloyi Aziyi. Ukrayina v Tsentral'no-Skhidniy Yevropi. Kyiv. Vol. 18. [In Ukrainian] 
9. Chukhlib T. (2015) Ponyattya "Ukrayina" ta "Ukrayinnyy" v ofitsiynomu dyskursi Viys'ka Zaporoz'koho: 1649 - 1659 rr. Ukrayina v Tsentral'no-Skhidniy Yevropi. Kyiv. Vol. 15. [In Ukrainian]

10. Chukhlib T. (2016) Ponyattya "Ukrayina", "Ukrayins'kyy", "Ukrayins'ka derzhava" v ofitsiynomu dyskursi Viys'ka Zaporoz'koho (1659 - 1665 rr.) Ukrayina v Tsentral'no-Skhidniy Yevropi. Kyiv. Vol. 16 [In Ukrainian]

11. Chukhlib T. (2017) Ponyattya "Ukrayina", "Ukrayins'kyy", "otchyzna", "narod" v ofitsiynomu dyskursi Viys'ka Zaporoz'koho (1666 - 1672 rr.) Ukrayina v Tsentral'no-Skhidniy Yevropi. Kyiv. Vol. 17 [In Ukrainian]

12. Chukhlib T. (2016) Ponyattya "Ukrayina", "Ukrayins'ki kozaky", "Ukrayins'kyy narod" v polozhennyakh Andrusivs'koho peremyr"ya ta mizhnarodniy ofitsiyniy dokumentatsiyi 1667 roku. Ukrayina mizh Pol'shcheyu ta Rosiyeyu. Materialy Mizhnarodnoyi naukovo-praktychnoyi konferentsiyi. Kyiv [In Ukrainian]

Тарас Чухлиб

ORCID: https://orcid.org/0000-0002-2604-4816 Доктор исторических наук, ведущий научный сотрудник Институт истории Украины НАН Украины УА. Грушевского, 4, Киев, 01001 , Украина kontrabas20@ukr.net

\section{Употребление политико-идентификаиионный словосочетаний "сторона Украчна", "тогобична Украина", "обеих сторон Днепр", "ту сторону Днепра", "Заднипрских сторона" (1673 - 1686 г2.)}

В статье раскрывается терминологическая сушность таких исторических понятий как "сторона Днепра", "ту сторону Днепра", "тогобична Украина", "заднепрских сторона", на основе диахронные-семантического анализа и других методов исследования текстов офиииальной документаиии Войска Запорожского, Короны Польской и Московского иарства за 1673 - 1687 гг. Автор делает следуюший вывод: данные понятийные словосочетание в указанный период широко используются правительствами этих государств в нескольких семантических значениях, в частности для обозначения как Правобережной, так и Аевобережной Украины. Также следует, ито подчиненная Войску Запорожскому территория в пределах бывших восточных воеводств Речи Посполитой получила постоянное политическое название "Украина", а также имела другие синонимичные самоназвания - "сторона Днепра", "тогобична Украина". Так же назывались и левобережные полки Войска Запорожского, которые были в политической зависимости Московского иарства и маркировались еше и как "заднепрская Украина", "ту сторону Днепра". Этот семантическо-синонимический ряд отображался в дипломатической и правительственной переписки государств Центральной, Восточной и Юго-Восточной Европы. Кроме того, в это же время функиионировали такие языковые словосочетание локализаиионноэтнонимического характера как "украинский народ".

Ключевые слова: "Украина", Войско Запорожское, "украинский народ", "сторона Днепра", "заднепрская сторона", Петр Дорошенко, Иван Самойлович.

Отримано: 12.12.2019p. 